Neurosurg Focus 10 (4):Article 3, 2001, Click here to return to Table of Contents

\title{
Bone morphogenetic protein in spinal fusion: overview and clinical update
}

\author{
Brian R. Subach, M.D., Regis W. Haid, M.D., Gerald E. Rodts, M.D., \\ AND Michael G. KAISER, M.D. \\ Department of Neurological Surgery, Spine Section, Emory University, Atlanta, Georgia
}

\begin{abstract}
The widespread use of fusion procedures in the management of spinal disorders has led investigators to explore the use of growth and differentiation factors in such procedures. As an adjuvant to allograft bone or as a replacement for harvested autograft, bone morphogenetic proteins (BMPs) appear to improve fusion rates after spinal arthrodesis in both animal models and humans, while reducing the donor-site morbidity previously associated with such procedures. The use of recombinant genetic technology in the production of BMP has improved the efficiency, cost effectiveness, and safety of producing and using such materials. Recombinant human BMP-2 (rhBMP-2), as one of the first factors identified in the process of endochondral bone formation, has been extensively researched over the past decade. The efficacy and dose profile of this differentiation factor in the context of various carrier substrates has been investigated. Based on the encouraging results of preliminary studies, the future role of rhBMP-2 may lie in its replacement of autologous bone grafting and, consequently, the reduced need for instrumented fixation, while concurrently improving overall fusion rates. The authors provide an overview of BMP and review its use in clinical and laboratory settings.
\end{abstract}

KEY WORDS • bone morphogenetic protein • spinal fusion • osteogenesis

Over 30 years ago, Marshall Urist and colleagues ${ }^{59,60}$ identified a group of protein extracts, derived from the ground substance of mature bovine bone, capable of inducing both cartilage and bone formation when implanted into the soft tissues of study animals. Aptly named BMPs by Urist, these glycoproteins comprise a subset of the transforming growth factor- $\beta$ family of related growth and differentiation factors. Of the more than 20 BMPs isolated to date, six appear to be structurally related to each other and capable of initiating the process of endochondral bone formation. The presence of such factors within the matrix of mature bone indicates a likely role in the regeneration and remodeling of bone structures after injury or repetitive stresses. ${ }^{4,9,17,21,38}$

\section{MOLECULAR BIOLOGY}

Each of the six known osteoinductive BMPs shares significant molecular similarities. Synthesized within the cell in precursor form, each molecule has a hydrophobic

Abbreviations used in this paper: $\mathrm{BMP}=$ bone morphogenetic protein; $\mathrm{cDNA}=$ complementary DNA; rhBMP = recombinant human BMP. leader or secretory sequence with the mature portion of the protein at the carboxy terminus marked by a highly conserved, seven-cysteine repeat. Each mature BMP begins as two monomers of 120 amino acids each, which undergo disulfide linkage dimerization to form either a homologous or a heterologous protein chain. In the case of BMP-2 and BMP-7, the specific structure was first identified by isolating the bovine protein from bone extracts. Oligonucleotide probes were then used to obtain the human cDNA sequence. The cDNA clones were then spliced into a viral expression vector and transfected into a carrier cell in a process called recombination. In the case of BMP-2, the cells used were Chinese hamster ovary cells, which produce the pure recombinant differentiation factor rhBMP-2 in large quantities in a process similar to fermentation. This process avoids potential complications related to the transmission of infectious materials from human donor bone tissue and eliminates the possibility of xenograft interactions with human recipients of BMP derived from bovine sources.

\section{OSTEOINDUCTIVE ROLE OF BMP}

To function as a suitable graft for bridging bone defects or fusing fracture lines and unstable motion segments, the prospective material would ideally possess three charac- 
teristics. First, the material would provide a source of primitive osteoprogenitor cells that, under the appropriate influence, would form osteoblasts and osteocytes (osteopromotion). Such precursor cells are, unfortunately, relatively scarce. Bone marrow, for example, contains only one osteprogenitor cell to approximately 50,000 nucleated cells in a young adult. This ratio may drop to $1: 200,000$ cells in an elderly individual afflicted by degenerative spinal disease. ${ }^{19}$ Despite techniques to concentrate marrow extracts, successful efforts have only resulted in a fivefold increase of the unfavorable cellular ratio. Second, the graft material would produce local growth factors to stimulate bone growth and vascularity in the area (osteoinduction). There are numerous reports in which investigators detail the complex interaction of various autocrine and paracrine growth factors released from fibroblasts, platelets, and even local hematoma at the site of injury. ${ }^{1,7,15,40}$ Finally, the third property of the graft material would be its ability to act as a scaffold for bone ingrowth (osteoconduction).

The osteoinductive role of BMP is multifaceted. Bone morphogenetic protein acts a chemotactic agent, a growth factor, and a differentiation factor. As a chemotactic factor, it initiates the recruitment of progenitor and stem cells toward the area of bone injury. Analysis of in vivo studies of the local effects of BMP indicates an initial migration of mesenchymal stem cells to the area of implantation far in excess of that supplied by bone marrow grafting. As a growth factor, it stimulates both angiogenesis and the proliferation of stem cells from surrounding mesenchymal tissues. As a differentiation factor, it promotes maturation of stem cells into chondrocytes, osteoblasts, and osteocytes.

Some cells respond to the growth factor aspect of BMP by altering their rates of proliferation. Yamaguchi, et al., ${ }^{62}$ have demonstrated this in vitro by quantifying cellular proliferation of the rat $\mathrm{C} 26$ calvarial osteoprogenitor cells after treatment with BMP-2. This BMP-2 effect, however, appears to maintain specificity for certain cell types. For example, although BMP-7 has been shown to be mitogenic for a human osteosarcoma cell line (TE-85), treatment with BMP-2 showed no measurable effect on proliferation. In contrast, treatment of an osteoblast cell line (MC3T3-E1) with BMP-4 results in a growth inhibition and a globally diminished proliferative index. Because of their effects on both mature and immature cell types, the complex interaction of BMPs clearly must be involved in the regulation of bone growth and maintenance.

Bone morphogenetic proteins also may initiate the differentiation of stem cells into a specific phenotype. For example, the rat calvarial stem cell line (C26) is considered multipotential, as such cells may be precursors for adipocytes, muscle cells, or osteoblasts. When BMP-2 is added to the culture medium, such cells become mature osteoblasts with increased surface expression of receptors for parathyroid hormone, alkaline phosphatase, and calcitonin. ${ }^{62}$ This effect may also be observed in bone marrow cells. For example, the mouse line of marrow cells (W-2017) may differentiate into either adipocytes or osteoblasts, depending on the specific hormonal influence. Treatment of such cells with BMP-2 results in both the differentiation of the cells into osteoblasts and the surface expression of receptors normally seen on mature cells.

\section{SOURCES OF BMP}

At present there are three ways to obtain growth and differentiation factors: extraction of the factors from animal or human bone matrix, production of a single factor by cellular hosts by using recombinant technology, and direct delivery to cells at the site of desired bone formation of the DNA encoding for the factor.

The first of these was initially used by Urist and colleague. ${ }^{59,60}$ From massive quantities of bovine bone, the group was able to extract a mixture of proteins found to stimulate bone growth in vivo. Commercially available today as NeOsteo (Sulzer Spinetech, Wheat Ridge, CO), this mixture of BMPs is derived through a well-engineered process of isolation from bovine sources. The precise combination of factors comprising this substance has not been fully characterized, but it appears to be reproducible through the manufacturer's process. This substance has shown promise in bridging both segmental skeletal defects in dogs and in inducing spinal fusion in animal models of posterolateral arthrodesis. ${ }^{14,16,23,24}$ Like other growth and differentiation factors, BMPs require a carrier substance to maintain adequate concentrations at the site of fusion. Substances such as natural coral (hydroxyapatite), collagen, and calcium sulfate have been investigated. ${ }^{23,24}$

The second method of obtaining bone growth and differentiation factors has previously been discussed (see Molecular Biology). The process of obtaining rhBMPs such as rhBMP-2 (Medtronic Sofamor Danek, Memphis, $\mathrm{TN}$, and Genetics Institute, Cambridge, MA) and rhBMP7 (Stryker Biotech, Hopkinton, MA) has been described. Such proteins differ from mixtures of extracted substances mainly in terms of purity of product. In original studies of these substances the authors focused on animal models of segmental bone defects in the appendicular skeleton of rats, sheep, and dogs. ${ }^{21,32}$ With considerable success, studies have compared rhBMP in a carrier with autologous grafting in a skeletal defect model. Gerhart, et al., ${ }^{32}$ showed the utility of rhBMP in healing segmental femoral defects in sheep. Shortly thereafter, recombinant BMP was applied in animal models of spinal fusion and, later, in humans.

The third strategy for engineering bone formation involves gene therapy, or the delivery of the appropriate gene or cDNA encoding for BMP to the local cells, rather than the actual factor. ${ }^{28}$ There are two obvious benefits to this strategy compared with recombinant technology. First, the cost of genetic manipulation is significantly less than that required to produce and market the purified rhBMP. Second, the potential for prolonged local production of the factor is greater when using gene therapy compared with the relatively short-lived effect of the $\mathrm{rhBMP} /$ carrier complex. Attempts to introduce BMP-2 cDNA into animal models are preliminary but have met with limited success. ${ }^{1,16,26}$

\section{EXPERIMENTAL EVIDENCE}

Analysis of early work in the isolation of proteins with osteoinductive activity suggested that BMP-2 and BMP-7 were primarily responsible for the effects observed in vivo. ${ }^{3,20,47,52}$ As a result, rhBMP-2, produced in a Chinese 


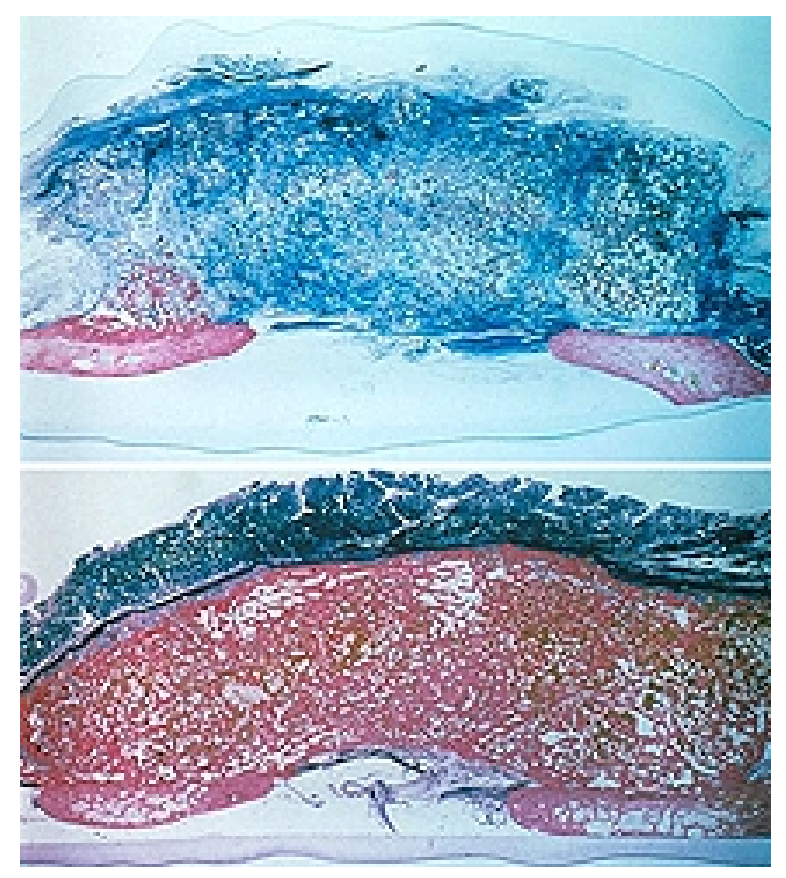

Fig. 1. Photomicrographs. Upper: Control intertransverse spinal fusion with carrier matrix alone (without BMP). The histological section demonstrates transverse processes at inferolateral corners with bridging collagen scar tissue and minimal bone formation. Lower: Intertransverse spinal fusion with rhBMP-2- impregnated carrier matrix. The histological section demonstrates transverse processes at inferolateral corners with abundant new membranous bone formation and minimal scar tissue.

hamster ovary cell line, was the first of these molecules studied in detail. Implantation of the recombinant factor in a rat model resulted in ectopic bone formation with a dose-effect relationship temporally identical to that of bone-derived extracts; however, the amount of pure rhBMP-2 required to induce formation of a given amount of bone was approximately 10 -fold greater than that required of the bone extract..$^{5,13,14,45}$ Such results implied an in vivo synergy in the mixture of differentiation factors obtained through the extraction process.

The ability to produce bone at ectopic sites, however, had little application in current spinal fusion techniques. Realizing the limitations inherent in autogenous and allogeneic bone grafting, investigators began applying BMP technology to animal models of spinal fusion. $2,6,11,22,29,30,33$, $34,44,48,54,55,63$ The authors of numerous studies, involving various concentrations of BMP in a variety of carrier substrates, have shown remarkable results. Early work by Boden and colleagues, ${ }^{12-14}$ Holliger and associates, ${ }^{39}$ and Schimandle, et al., ${ }^{54}$ compared rhBMP-2 with autologous bone graft in a rabbit posterolateral lumbar fusion model. Remarkably, all BMP-treated animals attained solid fusions across the operated level that were biomechanically stiffer and stronger than the autograft-only fusions observed in $42 \%$ of the control animals. In similar studies in a canine model the authors have also confirmed the efficacy of rhBMP-2 in producing mature fusion masses..$^{25}$ The canine study published by David, et al.,${ }^{25}$ demonstrated a dose dependence to the BMP effect, with greater concentrations producing greater effects; however, this finding contradicts work reported by Sandhu, et al., ${ }^{51-53}$ in a similar canine model, which showed BMP to be more effective than autologous bone graft but in a dose-independent manner. ${ }^{25}$ Most investigators developed the opinion that bone induction was a relatively simple process in lower species but was only indirectly applicable to human models. Consequently, research focused on developing spinal fusion models in primates. As a developmentally higher species, primates provide a more realistic test environment for evaluating the effectiveness of BMP. ${ }^{36,37}$ With this in mind, Boden, and coworkers ${ }^{10}$ studied a nonhuman primate model of intertransverse spinal fusion and demonstrated effective fusion rates after delivery of rhBMP-2 on a collagen sponge carrier via a minimally invasive approach (Fig. 1). Sandhu and colleagues ${ }^{53}$ went a step fur-

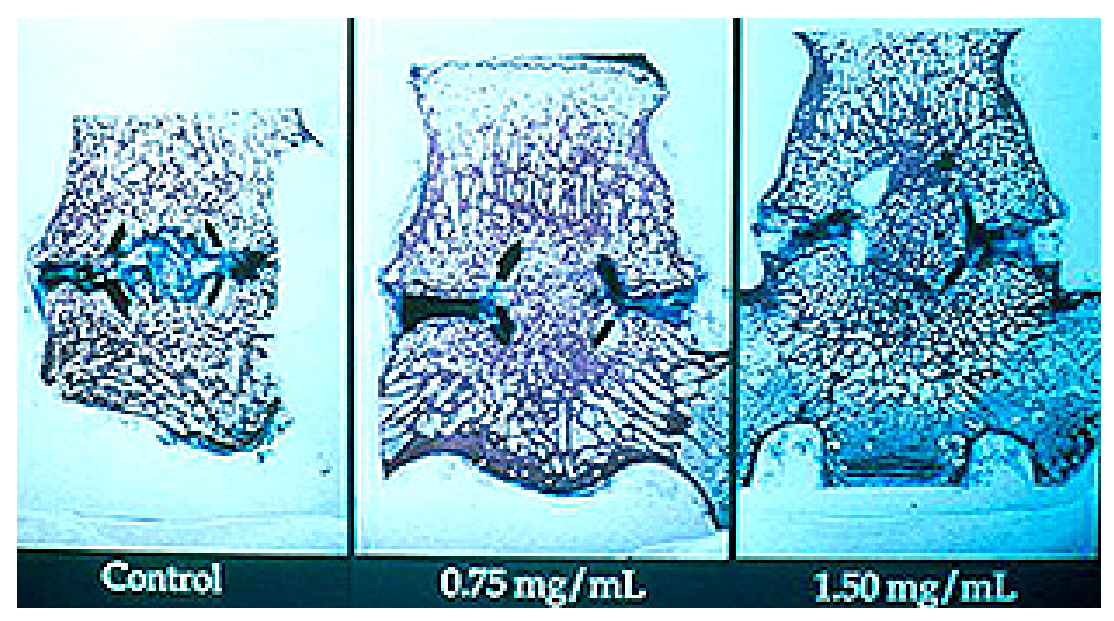

Fig. 2. Threaded titanium interbody cage implanted into the lumbar spine of a primate. The control group received the cage alone (left). The experimental groups received cages with rhBMP-2-impregnated sponges $(0.75 \mathrm{mg} / \mathrm{ml}$ [center] and $1.50 \mathrm{mg} / \mathrm{ml}[$ right]). The photographs show the actual spines at 6 months postsurgery. Left: A pseudarthrosis, with fibrous scar tissue within the cage, is present in the control spine. Center and Right: Mature bone bridging the interspace within the cage is shown in both BMP-2-treated spines. 


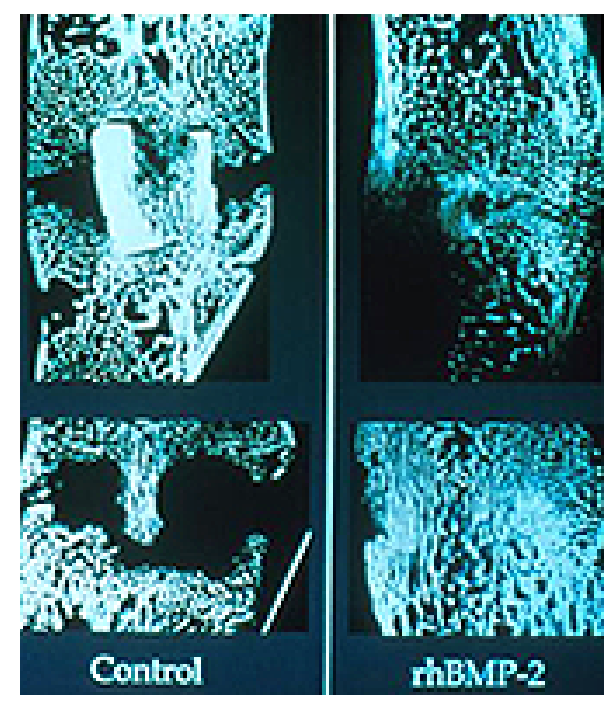

Fig. 3. Images demonstrating bone dowel interbody device implanted into the lumbar spine of a primate. The control group received a dowel with autograft. The experimental group received a bone dowel with an rhBMP-2-impregnated sponge placed inside. The images show the actual spines at 6 months postsurgery. A solid fusion is shown in one control animal (upper left), and resorption of the bone dowel/ autograft construct is shown in another control animal (lower left). Mature bone bridging the interspace with resorption of the dowel is shown in both animals that received a bone dowel treated with BMP-2-impregnated sponge (upper and lower right).

ther, demonstrating clinically, mechanically, and radiographically equivalent rates of rhBMP-2-induced spinal arthrodesis without having to decorticate the prospective fusion bed. Boden and colleagues, ${ }^{7,15,45}$ by adding rhBMP2 to autograft, were able to demonstrate subsequent induction of BMP-6, osteocalcin, and collagen within the graft itself.

In posterolateral fusion models some researchers attempted to replace autograft with a BMP/carrier complex, but internal fixation was still required. Attention was then focused on interbody spinal fusion techniques, which could possibly obviate the need for both autograft and fixation. ${ }^{18,31,41,42,49,50,56,57}$ Zdeblick, et al., ${ }^{64}$ performed threelevel anterior cervical fusions in goats; they used a BAK cage filled with either local autograft or a collagen-impregnated rhBMP-2 sponge. ${ }^{43,64}$ In three of seven animals in the autograft group there was radiographic evidence of pseudarthrosis, whereas in none of the BMP group did failure occur. The biomechanical stiffness of the BMP construct was equal to that of an autograft/cervical-plated level. Boden and associates ${ }^{8}$ performed the same procedure in the lumbar spine of primates: rhBMP-2 on a collagen carrier in both titanium threaded interbody cages and threaded bone dowels was delivered laparoscopically; fusion rates were improved over empty and autograftfilled cages (Figs. 2 and 3 ).

Preliminary results obtained in clinical studies have been encouraging. In a recent report of a randomized, prospective controlled clinical pilot study, Boden and colleagues $^{8}$ demonstrated that solid bone fusions had been achieved, by both clinical and radiographic criteria, in 11 patients who underwent anterior lumbar interbody fusion procedures in which they placed a tapered, threaded titanium cage filled with a rhBMP-2-impregnated collagen sponge (Fig. 4). Pain scores, as documented by the Oswestry Disability and the Short Form-36 questionnaires, improved concomitantly as fusion progressed. . $27,35,46,50,58,61^{2}$

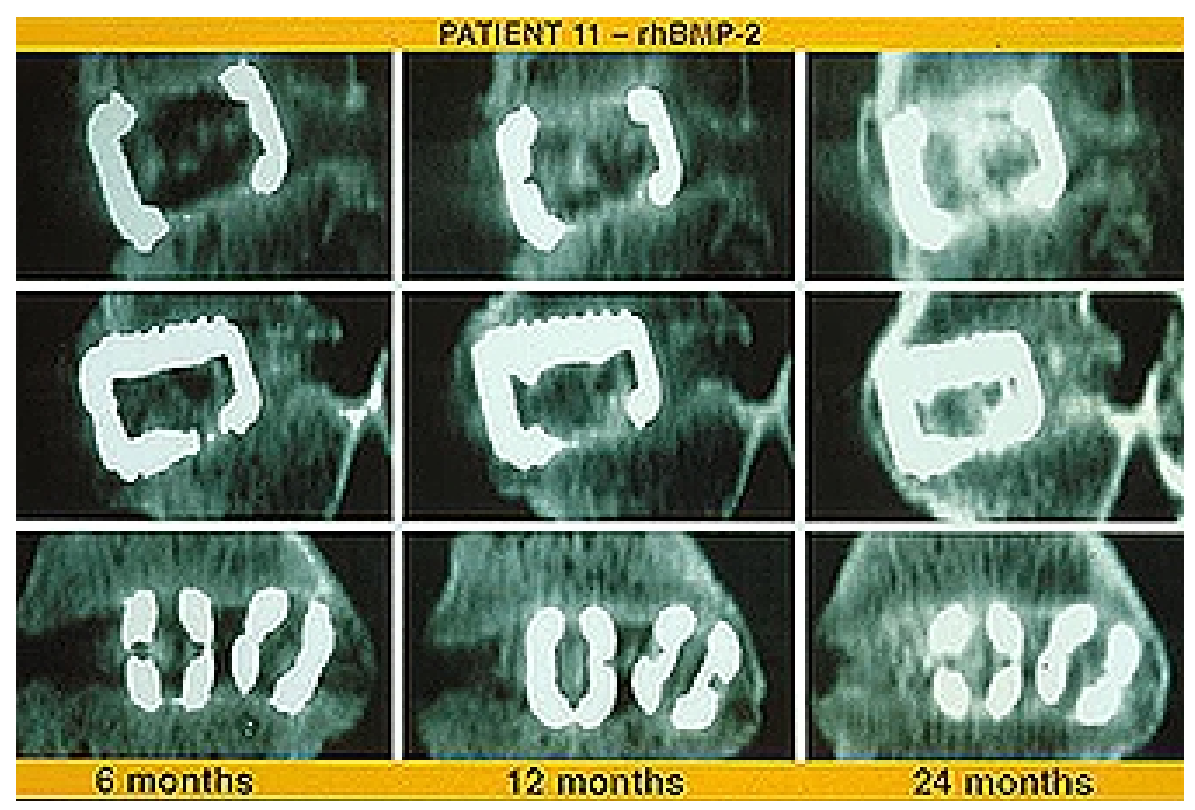

Fig. 4. Computerized tomography reconstructions obtained in a patient who received a threaded titanium cage with rhBMP-2 on a collagen sponge carrier. Upper: Sagittal scans of the left cage at 6, 12, and 24 months. Center: Scans obtained at 6, 12, and 24 months. Lower: Coronal scans obtained at 6, 12, and 24 months. All scans demonstrate fusion with increasing bone density over time. 


\section{SUMMARY}

Over the past decade research has shown the utility of using the differentiation factor BMP-2 to promote bone growth at the site of bone loss or injury. The in vivo roles of BMP-2 and its complex interactions with other growth and differentiation factors remain to be clarified. The use of BMP-2 as a means of replacing harvested autograft and obviating the need for internal fixation, each with its attendant morbidity, appears likely, based on results obtained in both animal and human studies. Although dose relationships and carrier substrates may provide continued investigational challenges, the use of recombinant technology and gene therapy in the field of bone fusion have been firmly established. It seems unlikely that Marshall Urist, who first first coined the term bone morphogenetic protein, could have envisioned the monumental strides and clinical progress researchers in the field have achieved over the past 30 years.

\section{Acknowledgments}

The authors wish to thank Medtronic Sofamor Danek for their continued support and assistance in preparation of the figures.

\section{References}

1. Aronow MA, Gerstenfeld LC, Owen TA, et al: Factors that promote progressive development of the osteoblast phenotype in cultured rat calvaria cells. J Cell Physiol 143:213-221, 1990

2. Arrington ED, Smith WJ, Chambers HG, et al: Complications of iliac crest bone graft harvesting. Clin Orthop 329:300-309, 1996

3. Asahina I, Sampath TK, Nishimura I, et al: Human osteogenic protein-1 induces both chondroblastic and osteoblastic differentiation of osteoprogenitor cells derived from newborn rat calvaria. J Cell Biol 123:921-933, 1993

4. Aspenberg P, Jeppsson C, Wang JS, et al: Transforming growth factor beta and bone morphogenetic protein 2 for bone ingrowth: a comparison using bone chambers in rats. Bone 19: 499-503, 1996

5. Aspenberg P, Turek T: BMP-2 for intramuscular bone induction: effect in squirrel monkeys is dependent on implantation site. Acta Orthop Scand 67:3-6, 1996

6. Banwart JC, Asher MA, Hassanein RS: Iliac crest bone graft harvest donor site morbidity. A statistical evaluation. Spine 20: 1055-1060, 1995

7. Boden SD, Hair G, Titus L, et al: Glucocorticoid-induced differentiation of fetal rat calvarial osteoblasts is mediated by bone morphogenetic protein-6. Endocrinology 138:2820-2828, 1997

8. Boden SD, Martin GJ, Horton WC, et al: Laparoscopic anterior spinal arthrodesis with rhBMP-2 in a titanium interbody threaded cage. J Spinal Disord 11:95-101, 1998

9. Boden SD, McCuaig K, Hair G, et al: Differential effects and glucocorticoid potentiation of bone morphogenetic protein action during rat osteoblast differentiation in vitro. Endocrinology 137:3401-3407, 1996

10. Boden SD, Moskovitz PA, Morone MA, et al: Video-assisted lateral intertransverse process arthrodesis: validation of a new minimally invasive lumbar spinal fusion technique in the rabbit and nonhuman primate (rhesus) models. Spine 21:2689-2697, 1996

11. Boden SD, Schimandle JH: Biologic enhancement of spinal fusion. Spine 20 (Suppl 24):113S-123S, 1995

12. Boden SD, Schimandle JH, Hutton WC, et al: In vivo evaluation of a resorbable osteoinductive composite as a graft substitute for lumbar spinal fusion. J Spinal Disord 10:1-11, 1997
13. Boden SD, Schimandle JH, Hutton WC: Lumbar intertransverse-process spinal arthrodesis using a bovine bone-derived osteoinductive protein. J Bone Joint Surg Am 77:1404-1417, 1995

14. Boden SD, Schimandle JH, Hutton WC: 1995 Volvo Award in basic sciences. The use of an osteoinductive growth factor for lumbar spinal fusion. Part II: study of dose, carrier, and species. Spine 20:2633-2644, 1995

15. Boden SD, Sumner DR: Biologic factors affecting spinal fusion and bone regeneration. Spine 20 (Suppl 24):102S-112S, 1995

16. Boden SD, Titus L, Hair G, et al: Lumbar spine fusion by local gene therapy with a cDNA encoding a novel osteoinductive protein (LMP-1). Spine 23:2486-2492, 1998

17. Boonen S, Broos P, Dequeker J, et al: The prevention or treatment of age-related osteoporosis in the elderly by systemic recombinant growth factor therapy (rhIGF-I or rhTGF beta): a perspective. J Intern Med 242:285-290, 1997

18. Calandruccio RA, Benton BF: Anterior lumbar fusion. Clin Orthop 35:63-8, 1964

19. Caplan AI: Mesenchymal stem cells. J Orthop Res 9:641-650, 1991

20. Centrella M, McCarthy TL, Canalis E: Transforming growth factor-beta and remodeling of bone. J Bone Joint Surg Am 73: 1418-1428, 1991

21. Cook SD, Baffes GC, Wolfe MW, et al: The effect of recombinant human osteogenic protein-1 on healing of large segmental bone defects. J Bone Joint Surg Am 76:827-838, 1994

22. Cook SD, Dalton JE, Tan EH, et al: In vivo evaluation of recombinant human osteogenic protein (rhOP-I ) implants as a bone graft substitute for spinal fusions. Spine 19:1655-1663, 1994

23. Damien CJ, Christel PS, Benedict JJ, et al: A composite of natural coral, collagen, bone protein and basic fibroblast growth factor tested in a rat subcutaneous model. Ann Chir Gynaecol Suppl 207:117-128, 1993

24. Damien CJ, Parsons JR, Benedict JJ, et al: Investigation of a hydroxyapatite and calcium sulfate composite supplemented with an osteoinductive factor. J Biomed Mater Res 24:639-654, 1990

25. David SM, Murakami T, Tabor OB, et al: Lumbar spinal fusion using recombinant human bone morphogenetic protein-2 (rhBMP-2): a randomized, blinded and controlled study. Transactions of the International Society for Study of the Lumbar Spine 22:14, 1995

26. Delloye C, Verhelpen M, d'Hemricourt J, et al: Morphometric and physical investigations of segmental cortical bone autografts and allografts in canine ulnar defects. Clin Orthop 282: 273-292, 1992

27. Fairbank JC, Couper J, Davies JB, et al: The Oswestry low back pain disability questionnaire. Physiotherapy 66:271-273, 1980

28. Fang J, Zhu YY, Smiley E, et al: Stimulation of new bone formation by direct transfer of osteogenic plasmid genes. Proc Natl Acad Sci USA 93:5753-5758, 1996

29. Fernyhough JC, Schimandle JJ, Weigel MC, et al: Chronic donor site pain complicating bone graft harvesting from the posterior iliac crest for spinal fusion. Spine 17:1474-1480, 1992

30. Fischgrund JS, James SB, Chabot MC, et al: Augmentation of autograft using rhBMP-2 and different carrier media in the canine spinal fusion model. J Spinal Disord 10:467-472, 1997

31. Fraser RD: Interbody, posterior, and combined lumbar fusions. Spine 20 (Suppl 24):167S-177S, 1995

32. Gerhart TN, Kirker-Head CA, Kriz MJ, et al: Healing segmental femoral defects in sheep using recombinant human bone morphogenetic protein. Clin Orthop 293:317-326, 1993

33. Goldberg VM, Stevenson S: Natural history of autografts and allografts. Clin Orthop 225:7-16, 1987

34. Goulet JA, Senunas LE, DeSilva GL, et al: Autogenous iliac crest bone graft. Complications and functional assessment. Clin Orthop 339:76-81, 1997 
35. Grevitt M, Khazim R, Webb J, et al: The short form-36 health survey questionnaire in spine surgery. J Bone Joint Surg Br 79:48-52, 1997

36. Hanisch O, Tatakis DN, Boskovic MM, et al: Bone formation and reosseointegration in peri-implantitis defects following surgical implantation of rhBMP-2. Int J Oral Maxillofac Implants 12:604-610, 1997

37. Hanisch O, Tatakis DN, Rohrer MD, et al: Bone formation and osseointegration stimulated by rhBMP-2 following subantral augmentation procedures in nonhuman primates. Int J Oral Maxillofac Implants 12:785-792, 1997

38. Hogan BL: Bone morphogenetic proteins: multifunctional regulators of vertebrate development. Genes Dev 10:1580-1594, 1996

39. Holliger EH, Trawick RH, Boden SD, et al: Morphology of the lumbar intertransverse process fusion mass in the rabbit model: a comparison between two bone graft materials-rhBMP-2 and autograft. J Spinal Disord 9:125-128, 1996

40. Kim SS, Denis F, Lonstein JE, et al: Factors affecting fusion rate in spondylolisthesis. Spine 15:979-984, 1990

41. Kozak JA. Heilman AE, O'Brien JP: Anterior lumbar fusion options. Technique and graft materials. Clin Orthop 300:45-51, 1994

42. Kumar A, Kozak JA, Doherty BJ, et al: Interspace distraction and graft subsidence after anterior lumbar fusion with femoral strut allograft. Spine 18:2393-2400, 1993

43. Kuslich SD, Ulstrom CL, Griffith SL, et al: The Bagby and Kuslich method of lumbar interbody fusion. History, techniques, and 2-year follow-up results of a United States prospective, multicenter trial. Spine 23:1267-1279, 1998

44. Laurie SW, Kaban LB, Mulliken JB, et al: Donor-site morbidity after harvesting rib and iliac bone. Plast Reconstr Surg 73: 933-938, 1984

45. Martin GJ, Boden SD, Morone MA, et al: Posterolateral intertransverse process spinal fusion arthrodesis with rhBMP-2 in a nonhuman primate: important lessons learned regarding dose, carrier, and safety. J Spinal Disord 12:179-186, 1999

46. McHorney CA, Ware JE, Lu JF, et al: The MOS 36-item Short Form Health Survey (SF-36): III. Tests of data quality, scaling assumptions, and reliability across diverse patient groups. Med Care 32:40-66, 1994

47. Muschler GF, Hyodo A, Manning T, et al: Evaluation of human bone morphogenetic protein 2 in a canine spinal fusion model. Clin Orthop 308:229-240, 1994

48. Rawlinson JN: Morbidity after anterior cervical decompression and fusion. The influence of the donor site on recovery, and the results of a trial of surgibone compared to autologous bone. Acta Neurochir 131:106-118, 1994

49. Ray CD: Threaded titanium cages for lumbar interbody fusions. Spine 22:667-680, 1997
50. Sacks S: Anterior interbody fusion of the lumbar spine. Indications and results in 200 cases. Clin Orthop 44:163-170, 1966

51. Sandhu HS, Kanim LE, Kabo JM: Effective doses of recombinant human bone morphogenetic protein-2 in experimental spinal fusion. Spine 21:2115-2122, 1996

52. Sandhu HS, Kanim LE, Kabo JM, et al: Evaluation of rhBMP2 with an OPLA carrier in a canine posterolateral (transverse process) spinal fusion model. Spine 20:2669-2682, 1995

53. Sandhu HS, Kanim LEA, Toth JM, et al: Experimental spinal fusion with recombinant human bone morphogenetic protein-2 without decortication of osseous elements. Spine 22: 1171-1180, 1997

54. Schimandle JH, Boden SD, Hutton WC: Experimental spinal fusion with recombinant human bone morphogenetic, protein2. Spine 20:1326-1337, 1995

55. Schnee CL, Freese A, Weil RJ, et al: Analysis of harvest morbidity and radiographic outcome using autograft for anterior cervical fusion. Spine 22:2222-2227, 1997

56. Sorensen KH: Anterior interbody lumbar spine fusion for incapacitating disc degeneration and spondylolisthesis. Acta Orthop Scand 49:269-277, 1978

57. Stauffer RN, Coventry MB: Anterior interbody lumbar spine fusion. Analysis of Mayo Clinic series. J Bone Joint Surg Am 54:756-768, 1972

58. Stewart AL, Hays RD, Ware JE: The MOS short-form general health survey. Reliability and validity in a patient population. Med Care 26:724-735, 1988

59. Urist MR: Bone: formation by autoinduction. Science 150:893-899, 1965

60. Urist MR, Strates BS: Bone morphogenetic protein. J Dent Res Suppl 50:1392-1406, 1971

61. Ware JE, Sherbourne CD: The MOS 36-item short form health survey (SF-36): I. Conceptual framework and item selection. Med Care 30:473-483, 1992

62. Yamaguchi A, Katagiri T, Ikeda T, et al: Recombinant human bone morphogenetic protein-2 stimulates osteoblastic maturation and inhibits myogenic differentiation in vitro. J Cell Biol 113:681-687, 1991

63. Younger EM, Chapman MW: Morbidity at bone graft donor sites. J Orthop Trauma 3:192-195, 1989

64. Zdeblick TA, Ghanayem AJ, Rapoff AJ, et al: Cervical interbody fusion cages. An animal model with and without bone morphogenetic protein. Spine 23:758-766, 1998

Manuscript received March 19, 2001.

Accepted in final form April 2, 2001.

Address reprint requests to: Brian R. Subach, M.D., Neurosurgery, 478 Peachtree Street, Suite 607A, Atlanta, Georgia 30308. 